\title{
Pengaruh Information Quality dan Trust Terhadap Intensi Pembelian Secara Online Pada Lady Reptile
}

\author{
Vanessa Ellena Lodan \\ Program Studi IBM, Fakultas Entrepreneurial Business \\ Universitas Ciputra \\ Mohamad Yusak Anshori \\ Universitas Ciputra
}

\begin{abstract}
Penelitian ini bertujuan untuk mengetahui pengaruh information quality dan trust terhadap intensi pembelian secara online pada Lady Reptile. Populasi dalam penelitian ini adalah konsumen yang telah melakukan pembelian produk secara online pada Lady Reptile. Jumlah sampel yang digunakan sebanyak 68 responden dengan menggunakan metode pengambilan sampel non probabilitas yaitu convenience sampling. Teknik analisa data yang digunakan dalam penelitian ini adalah analisis regresi linier berganda dengan menggunakan program SPSS 20.0. Analisis ini meliputi uji validitas dan reliabilitas, analisis regresi linier berganda, pengujian hipotesis melalui uji $F$ dan uji t, analisis koefisien korelasi $(R)$ dan determinasi berganda $\left(R^{2}\right)$, analisis koefisien korelasi $(r)$ dan determinasi parsial $\left(r^{2}\right)$, serta uji asumsi klasik. Hasil penelitian menunjukkan bahwa information quality dan trust berpengaruh terhadap intensi pembelian konsumen secara online pada Lady Reptile, baik secara simultan maupun parsial.
\end{abstract}

Keywords:

Information quality, trust, intensi pembelian, lady reptile 


\section{PENDAHULUAN}

Hobi memelihara hewan telah menjadi gaya hidup pada masyarakat saat ini. Rutinitas kerja, kemacetan, kesibukan, dan tuntutan pekerjaan yang serba cepat telah menjadi keseharian sebagian besar masyarakat kota. Untuk menghilangkan kejenuhan dan stres tersebut, banyak orang memelihara hewan kesayangan seperti anjing, kucing, ikan, burung, dan sebagainya. Bahkan saat ini, orang-orang mulai memilih reptil sebagai hewan peliharaan. Banyaknya penghobi hewan peliharaan melahirkan peluang usaha pet shop, yaitu sebuah usaha ritel yang melayani pembelian berbagai jenis hewan sesuai dengan spesifikasi satwa yang dijual.

Seiring dengan perkembangan teknologi, usaha pet shop menjadi semakin luas dengan media internet. Internet tidak hanya sebagai media untuk mendapatkan informasi secara cepat, tetapi sudah menjadi tren dan kebutuhan bagi masyarakat untuk membantu dalam menjalankan kegiatan sehari-hari. Selain sebagai media untuk mendapatkan informasi secara cepat, internet juga dapat dimanfaatkan untuk berbisnis, artinya dapat digunakan untuk mendapatkan uang dengan menjalankan aktivitas bisnis secara online (Utomo, 2009:4). Dengan semakin tingginya aktivitas masyarakat di dunia maya, semakin tinggi pula minat orang untuk berbisnis di toko online. Menurut Susrini (2010:13), toko online adalah sebuah toko atau tempat berjualan yang sebagian besar aktivitasnya berlangsung secara online di internet.

Perkembangan teknologi internet telah mengundang para pebisnis untuk mengganti atau menambah sistem pemasaran, dari awalnya konvensional dengan cara tatap muka langsung antara penjual dan pembeli sehingga menjadi pemasaran secara online yang mana antara penjual dan pembeli tidak harus bertatap muka. Bagi konsumen, penggunaan toko online akan membuat waktu belanja menjadi lebih singkat. Konsumen tidak perlu lagi bersusah payah keliling ke berbagai pertokoan untuk membandingkan harga dan mendapatkan barang yang diinginkan. Selain itu, toko online dapat mengatasi masalah jauhnya jarak dan perbedaan waktu karena dapat dilakukan kapan saja dan di mana saja, apalagi teknologi internet sudah bisa diakses melalui layanan mobile (Handayani, 2010:10). Berbagai keuntungan yang bisa didapatkan konsumen melalui toko online ini merupakan potensi yang bisa dioptimalkan oleh para penjual.

Meskipun toko online memberikan berbagai keuntungan bagi konsumen, namun juga memiliki sisi negatif yaitu memungkinkan adanya hacking ke situs atau pencurian data pelanggan, tidak tepat waktu dalam pengiriman barang, serta jenis dan kualitas barang tidak sesuai dengan keinginan konsumen yang mana dapat diantisipasi dengan melakukan pengepakan barang yang bagus dan menggunakan jasa pengiriman yang terpercaya (Utomo, 2009:10). Selain itu, juga terdapat ancaman penipuan. Untuk toko online yang telah terbukti melakukan penipuan akan masuk kategori blacklist seller dan untuk customer akan masuk kategori blacklist customer. Begitu juga dengan toko online yang terpercaya akan masuk dalam kategori recommended dan trusted seller. Melalui media internet dan jejaring sosial, penjual dan konsumen dapat bertukar informasi sehingga informasi tersebut dapat menjadi acuan dalam melakukan transaksi online.

Salah satu usaha pet shop yang memanfaatkan media internet untuk meningkatkan penjualan adalah Lady Reptile dengan alamat email: lady.reptile@yahoo.com. Usaha ini berdiri pada bulan Mei 2010. Lady Reptile menjual 
beragam hewan reptil dengan menggunakan gecko sebagai icon satwa yang dijual.

Media pemasaran yang digunakan oleh Lady Reptile melalui online yaitu internet dan BlackBerry Messenger (BBM). Untuk mendukung penjualan, selama ini selalu disertakan berbagai informasi yang diperlukan, diantaranya adalah jenis hewan, jenis kelamin, usia, tanggal lahir, kondisi kesehatan terakhir, ukuran, ada tidaknya cacat hewan, motif dan warna, harga, garansi, serta cara pemeliharaan dan perawatan.

Informasi tersebut diharapkan dapat memudahkan para calon pembeli untuk me-review produk dan berguna bagi konsumen untuk tertarik membeli atau tidak. Berbagai informasi tersebut dinilai berkualitas karena menyangkut kehidupan hewan itu sendiri yang bisa menjadi pertimbangan konsumen untuk melakukan pembelian. Tidak menutup kemungkinan konsumen diperkenankan melakukan kontak langsung dengan penjual untuk memperjelas berbagai informasi tersebut. Oleh karena itu untuk memudahkan transaksi, selalu disertakan contact person seperti nama, nomor telepon, alamat email, pin BlackBerry Messenger (BBM), alamat YM, Facebook, dan lain-lain sehingga konsumen tidak ragu untuk bertransaksi. Informasi menjadi komponen penting dalam pembelian karena informasi yang semakin berkualitas bisa mendatangkan daya tarik bagi konsumen untuk melakukan pembelian.

Kepercayaan (trust) untuk penjualan online memiliki peran yang sangat menentukan karena banyaknya perilaku kejahatan dalam dunia online. Berbagai bentuk penipuan sering terjadi melalui media online, sehingga kepercayaan konsumen mutlak untuk dipertahankan.

Menurut Utomo (2009:8), kepercayaan konsumen merupakan faktor utama. Hal ini dikarenakan kegiatan bisnis yang dilakukan adalah secara online, tidak bertatap muka langsung antara penjual dan pembeli. Pembeli akan memasukkan dan memberikan data-data pribadi mereka dan pembeli akan mempunyai keterbatasan dalam mengawasi penjual, apakah akan menyalahgunakan informasi yang diberikan atau tidak. Oleh karena itu, kepercayaan seperti ini perlu diperhatikan sehingga pembeli akan merasa nyaman untuk berbelanja dan memberikan data pribadi mereka. Jika kepercayaan ini dapat dibangun, maka jumlah pembelian akan dapat meningkat.

Fluktuasi tingkat penjualan yang dicapai Lady Reptile menunjukkan bahwa perusahaan belum mampu meningkatkan intensi pembelian yang baik pada konsumen. Faktor-faktor seperti pengaruh information quality dan trust belum tentu dapat meningkatkan intensi pembelian secara online pada Lady Reptile secara optimal, sehingga perlu dievaluasi kembali beserta seberapa besar pengaruhnya terhadap intensi pembelian.

\section{TINJAUAN PUSTAKA}

\subsection{Pengertian Kualitas Informasi (Information Quality)}

Menurut Kirk dalam Popovic dan Habjan (2012:126) bahwa kualitas informasi merupakan masalah yang penting untuk pengambilan keputusan, termasuk pula untuk pelaku bisnis maupun bagi konsumen. Informasi berguna dalam pengambilan keputusan. Ditambahkan oleh Alba dan Hutchinson dalam Avitia, et al., (2011:5) bahwa informasi berhubungan dengan pengetahuan konsumen sehingga informasi tersebut menjadi prioritas bagi konsumen untuk dikumpulkan sehingga bisa melakukan evaluasi atas keputusan yang akan diambil. 
$2.2 \quad$ Klasifikasi Kualitas Informasi Kualitas informasi bisa diklasifikasikan menjadi beberapa klasifikasi yaitu: intrinsic data quality, contextual data quality, representational data quality, dan accesbility data quality (Wang dan Strong dalam Alkhattabi, et al., 2010:345). Lebih lanjut, Rieh dan Hilligoss (2008:51) menjelaskan bahwa sebuah informasi dinilai berkualitas apabila memiliki beberapa unsur, diantaranya adalah informasi harus akurat, adanya pihak yang bertanggungjawab untuk informasi, informasi harus objektif, informasi yang diberikan sesuai dengan perkembangan terbaru, serta informasi yang ada harus cukup komprehensif.

\subsection{Pengertian Kepercayaan (Trust)}

Dixit dan Datta dalam Zhu, et al., (2011:2) menyatakan: "Trust has a very important role in reducing perceived risks". Maksudnya ketika konsumen memiliki kepercayaan maka risiko yang dirasakan oleh konsumen semakin rendah mengingat konsumen yang memiliki kepercayaan berarti tingkat kecemasan yang dirasakan konsumen semakin rendah.

\subsection{Faktor Penentu Kepercayaan}

Mayer, et al. dalam Hong dan Hwihyung Cho (2011:470) menyatakan bahwa terdapat tiga faktor penentu dari tingkat kepercayaan konsumen terhadap peritel online (e-commerce) yaitu: ability (or competence), benevolence, dan integrity. Penjelasan dari setiap faktor tersebut adalah sebagai berikut:

- Ability, yaitu kemampuan peritel online untuk memberikan layanan yang lebih baik dibandingkan yang lain yaitu meliputi: pengetahuan terhadap produk, kecepatan layanan antar (pengiriman), kualitas customer service.

- Benevolence, yaitu keyakinan konsumen terhadap peritel online bahwa peritel online tidak hanya memikirkan masalah bisnis semata dengan konsumen tetapi juga memberikan perlindungan atas kepentingan konsumen.

- Integrity, yaitu keyakinan konsumen bahwa peritel online akan mampu memberikan layanan yang terbaik untuk konsumen.

\subsection{Pengertian Intensi Pembelian}

Ganguli, et al., (2010:307)

menyatakan: "Purchase intention is concerned with the likelihood to purchase products online". Intensi pembelian adalah kemungkinan untuk melakukan pembelian online. Ditambahkan: "Purchase intention is the final consequence of a number of cues for the e-commerce customer". Bahwa intensi pembelian adalah konsekuensi indikator final untuk layanan e-commerce untuk pelanggan. Terdapat berbagai indikator dari purchase intention, sebagai berikut (Ganguli, et al., 2010:330):

a. Konsumen berkeinginan untuk melanjutkan menggunakan online shop untuk membeli produk dan jasa di waktu yang akan datang. Keinginan yang berkelanjutan menunjukkan sebuah intensi pembelian. Intensi pembelian yang tinggi akan mampu mendorong konsumen melakukan pembelian, dan memperlihatkan pembelian yang akan dilakukan dengan didasari oleh keinginan dalam diri konsumen.

b. Konsumen akan merekomendasikan kepada orang lain untuk menggunakan online shop yang diketahui. Konsumen dengan intensi pembelian tinggi maka terdapat kecenderungan konsumen mereferensikan informasi tersebut kepada orang lain. Hal ini tidak terlepas dari tendensi keinginan konsumen untuk dinilai berjasa bagi konsumen lainnya sehingga dengan memberikan informasi 
yang berharga berarti konsumen dihargai di lingkungannya.

c. Konsumen akan melakukan transaksi dalam waktu dekat. Keinginan untuk melakukan transaksi merupakan sebuah bentuk gambaran tingginya intensitas pembelian. Pembelian konsumen didasari oleh kemauan dan keinginan sehingga ketika kemauan dan keinginan tersebut tinggi berarti kemungkinan pembelian terjadi juga tinggi.

\section{METODOLOGI}

\subsection{Deskripsi Penelitian}

Metode penelitian yang digunakan dalam penelitian ini adalah metode causal research, yaitu sebuah penelitian konklusif dengan tujuan untuk mendapatkan pengujian yang tepat dan benar dalam penarikan kesimpulan mengenai hubungan sebab akibat antar variabel-variabel, sementara konklusif sendiri berarti sebagai penelitian dengan tujuan untuk menguji dan membuktikan sesuatu teori dan pendapat. Variabel-variabel yang menjadi variabel bebas adalah information quality $\left(\mathrm{X}_{1}\right)$ dan trust $\left(\mathrm{X}_{2}\right)$ terhadap intensi pembelian (Y) sebagai variabel terikat.

Jenis data dalam penelitian ini adalah data kualitatif dan data kuantitatif. Data kualitatif berupa data yang berbentuk kata, kalimat, skema, dan gambar, seperti literatur serta teori-teori yang berkaitan dengan penelitian. Sedangkan data kuantitatif berupa data yang berbentuk angka atau data kualitatif yang diangkakan.

\subsection{Populasi dan Sampel}

Dalam penelitian ini, target populasi merupakan konsumen yang pernah melakukan pembelian secara online pada Lady Reptile sebanyak 212 konsumen.

Metode dari pemilihan sampel untuk penelitian ini adalah non probability sampling dan teknik yang dipilih adalah convenience sampling, yaitu teknik mendapatkan sampel dengan memperhatikan kemudahan mendapatkan data. Sampel yang didapatkan adalah sampel yang diperoleh menurut keinginan penulis (Kuncoro, 2009:138).

Untuk penentuan besarnya sampel, dengan mengetahui jumlah pelanggan online sebanyak 212, maka penentuan jumlah sampel dengan menggunakan rumus Slovin (Setiawan, 2009:6) sebagai berikut:

$$
n=\frac{N}{1+N e^{2}}
$$

Dimana:

$n=$ Ukuran sampel

$\mathrm{N}=$ Ukuran populasi

$e=$ Persen kelonggaran ketidaktelitian karena kesalahan pengambilan sampel yang masih dapat ditolerir (toleransi terjadinya kesalahan, taraf signifikansi umumnya 5\% - 10\%)

$$
n=\frac{212}{1+212(0,10)^{2}}=68
$$

Berdasarkan perhitungan tersebut, maka jumlah sampel yang ditetapkan adalah sebanyak 68 sampel.

\subsection{Metode Pengumpulan Data}

Metode pengumpulan data yang digunakan dalam penelitian ini adalah:

a. Metode survey, dilakukan dengan membagikan kuesioner kepada konsumen Lady Reptile. Kuesioner adalah teknik pengumpulan data yang efisien jika penulis tahu dengan pasti variabel yang akan diukur dan tahu apa yang bisa diharapkan konsumen (Sugiyono, 2008:199).

b. Observasi, yang dilakukan bertujuan untuk mencari data-data pelengkap yang dibutuhkan dalam penelitian ini, seperti data penjualan Lady Reptile. 
IV. ANALISIS

\subsection{Uji Validitas}

Validitas menjawab pertanyaan apakah instrumen penelitian yang telah disusun benar-benar telah akurat, sehingga mampu mengukur apa yang seharusnya diukur (Kuncoro, 2009:172). Kriteria dalam uji validitas ini adalah nilai signifikansi hubungan skor tiap instrumen dengan skor totalnya, nilai signifikansinya harus $<0,05$.

Tabel 1.

Uji Validitas Data

\begin{tabular}{|c|c|c|c|c|}
\hline \multirow{2}{*}{ Kode } & \multirow{2}{*}{ Pernyataan } & \multicolumn{3}{|c|}{ Validitas Information Quality } \\
\hline & & Korelasi & Sig. & Simpulan \\
\hline $\mathrm{X}_{1.1}$ & Informasi yang diberikan Lady Reptile akurat. & 0,760 & 0,000 & Valid \\
\hline $\mathrm{X}_{1.2}$ & $\begin{array}{l}\text { Lady Reptile memberikan nomor kontak yang jelas } \\
\text { untuk informasi. }\end{array}$ & 0,662 & 0,000 & Valid \\
\hline $\mathrm{X}_{1.3}$ & $\begin{array}{l}\text { Informasi yang diberikan Lady Reptile sesuai dengan } \\
\text { keadaan yang sebenarnya (objektif). }\end{array}$ & 0,767 & 0,000 & Valid \\
\hline $\mathrm{X}_{1.4}$ & $\begin{array}{l}\text { Informasi yang diberikan Lady Reptile adalah } \\
\text { informasi terbaru (update). }\end{array}$ & 0,634 & 0,000 & Valid \\
\hline \multirow{2}{*}{ Kode } & \multirow{2}{*}{ Pernyataan } & \multicolumn{3}{|c|}{ Validitas Trust } \\
\hline & & Korelasi & Sig. & Simpulan \\
\hline $\mathrm{X}_{2.1}$ & $\begin{array}{l}\text { Lady Reptile memiliki pengetahuan mengenai produk } \\
\text { yang dijual dengan baik. }\end{array}$ & 0,728 & 0,000 & Valid \\
\hline $\mathrm{X}_{2.2}$ & Lady Reptile tepat waktu dalam pengiriman barang. & 0,745 & 0,000 & Valid \\
\hline $\mathrm{X}_{2.3}$ & Lady Reptile menjaga data-data pribadi konsumen. & 0,743 & 0,000 & Valid \\
\hline $\mathrm{X}_{2.4}$ & $\begin{array}{l}\text { Lady Reptile mampu memberikan layanan yang terbaik } \\
\text { untuk konsumen. }\end{array}$ & 0,658 & 0,000 & Valid \\
\hline \multirow{2}{*}{ Kode } & \multirow{2}{*}{ Pernyataan } & \multicolumn{3}{|c|}{ Validitas Intensi Pembelian } \\
\hline & & Korelasi & Sig. & Simpulan \\
\hline $\mathrm{Y}_{1}$ & $\begin{array}{l}\text { Saudara berkeinginan untuk melanjutkan menggunakan } \\
\text { Lady Reptile untuk membeli produk dan jasa diwaktu } \\
\text { yang akan datang. }\end{array}$ & 0,908 & 0,000 & Valid \\
\hline $\mathrm{Y}_{2}$ & $\begin{array}{l}\text { Saudara akan merekomendasikan Lady Reptile kepada } \\
\text { orang lain. }\end{array}$ & 0,923 & 0,000 & Valid \\
\hline $\mathrm{Y}_{3}$ & Saudara akan melakukan transaksi dalam waktu dekat. & 0,901 & 0,000 & Valid \\
\hline
\end{tabular}

Berdasarkan Tabel 1. diketahui bahwa uji validitas pada semua pernyataan variabel penelitian menghasilkan nilai signifikansi $<0,05$ sehingga semua pernyataan yang membentuk variabel penelitian ini dinyatakan valid.

\subsection{Uji Reliabilitas}

Reliabilitas merupakan konsistensi dan stabilitas dari suatu skor (Kuncoro, 2009:175). Jika nilai cronbach alpha $>0,6$ dan nilai cronbach alpha if item deleted pada masing-masing pernyataan $<$ nilai cronbach alpha maka item tersebut reliable (Priyatno, 2009:172). 
Tabel 2.

Uji Reliabilitas Data

\begin{tabular}{|c|c|c|c|c|}
\hline \multirow[b]{2}{*}{ Kode } & \multirow[b]{2}{*}{ Pernyataan } & \multicolumn{3}{|c|}{ Reliabilitas Information Quality } \\
\hline & & $\begin{array}{l}\text { Croanbach } \\
\text { Alpha }\end{array}$ & $\begin{array}{c}\text { Croanbach } \\
\text { Alpha if Item } \\
\text { Deleted }\end{array}$ & Simpulan \\
\hline $\mathrm{X}_{1.1}$ & Informasi yang diberikan Lady Reptile akurat. & \multirow{4}{*}{0,668} & 0,572 & Reliabel \\
\hline $\mathrm{X}_{1.2}$ & $\begin{array}{l}\text { Lady Reptile memberikan nomor kontak yang } \\
\text { jelas untuk informasi. }\end{array}$ & & 0,622 & Reliabel \\
\hline $\mathrm{X}_{1.3}$ & $\begin{array}{l}\text { Informasi yang diberikan Lady Reptile sesuai } \\
\text { dengan keadaan yang sebenarnya (objektif). }\end{array}$ & & 0,545 & Reliabel \\
\hline $\mathrm{X}_{1.4}$ & $\begin{array}{l}\text { Informasi yang diberikan Lady Reptile adalah } \\
\text { informasi terbaru (update). }\end{array}$ & & 0,650 & Reliabel \\
\hline \multirow[b]{2}{*}{ Kode } & \multirow[b]{2}{*}{ Pernyataan } & \multicolumn{3}{|c|}{ Reliabilitas Trust } \\
\hline & & $\begin{array}{l}\text { Croanbach } \\
\text { Alpha }\end{array}$ & $\begin{array}{l}\text { Croanbach } \\
\text { Alpha if Item } \\
\text { Deleted }\end{array}$ & Simpulan \\
\hline $\mathrm{X}_{2.1}$ & $\begin{array}{l}\text { Lady Reptile memiliki pengetahuan mengenai } \\
\text { produk yang dijual dengan baik. }\end{array}$ & \multirow{4}{*}{0,687} & 0,639 & Reliabel \\
\hline $\mathrm{X}_{2.2}$ & $\begin{array}{l}\text { Lady Reptile tepat waktu dalam pengiriman } \\
\text { barang. }\end{array}$ & & 0,587 & Reliabel \\
\hline $\mathrm{X}_{2.3}$ & $\begin{array}{l}\begin{array}{l}\text { Lady Reptile menjaga } \\
\text { konsumen. }\end{array} \\
\text { data-data }\end{array}$ & & 0,605 & Reliabel \\
\hline \multirow[t]{2}{*}{$\mathrm{X}_{2.4}$} & $\begin{array}{l}\text { Lady Reptile mampu memberikan layanan yang } \\
\text { terbaik untuk konsumen. }\end{array}$ & & 0,652 & Reliabel \\
\hline & \multirow[b]{2}{*}{ Pernyataan } & \multicolumn{3}{|c|}{ Reliabilitas Intensi Pembelian } \\
\hline Kode & & $\begin{array}{l}\text { Croanbach } \\
\text { Alpha }\end{array}$ & $\begin{array}{c}\text { Croanbach } \\
\text { Alpha if Item } \\
\text { Deleted }\end{array}$ & Simpulan \\
\hline $\mathrm{Y}_{1}$ & $\begin{array}{l}\text { Saudara berkeinginan untuk melanjutkan } \\
\text { menggunakan Lady Reptile untuk membeli } \\
\text { produk dan jasa diwaktu yang akan datang. }\end{array}$ & \multirow{3}{*}{0,896} & 0,866 & Reliabel \\
\hline $\mathrm{Y}_{2}$ & $\begin{array}{l}\text { Saudara akan merekomendasikan Lady Reptile } \\
\text { kepada orang lain. }\end{array}$ & & 0,824 & Reliabel \\
\hline $\mathrm{Y}_{3}$ & $\begin{array}{l}\text { Saudara akan melakukan transaksi dalam waktu } \\
\text { dekat. }\end{array}$ & & 0,866 & Reliabel \\
\hline
\end{tabular}

Tabel 2. menunjukkan semua variabel penelitian ini mempunyai nilai cronbach alpha $>0,6$ dan nilai cronbach alpha if item deleted < cronbach alpha, sehingga bisa dinyatakan bahwa keseluruhan indikator dari semua variabel penelitian ini dinyatakan reliabel.

\subsection{Analisis Regresi Linier Berganda}

Data yang terkumpul dalam penelitian ini akan dianalisis dengan menggunakan teknik analisis statistik dengan menggunakan program SPSS, yang mana rumus statistik yang digunakan adalah Linier Multiple Regression (Regresi Linier Berganda). Regresi adalah studi bagaimana satu variabel yaitu variabel terikat 
dipengaruhi oleh satu atau lebih variabel lain yaitu variabel bebas. Dengan tujuan mengestimasi dan atau memprediksikan nilai rata-rata variabel terikat didasarkan pada nilai variabel bebas yang diketahui. Untuk itu, tujuan utama regresi adalah untuk memprediksi nilai variabel terikat berdasarkan satu atau lebih variabel bebas (Widarjono, 2010:9).

Tabel 3.

Hasil Analisis Regresi Linier Berganda

\begin{tabular}{|c|c|c|c|c|c|}
\hline Variabel Bebas & Koefisien & $\begin{array}{l}\text { Taksiran } \\
\text { Koefisien } \\
\end{array}$ & $\mathbf{t}_{\text {hitung }}$ & Sig. & r parsial \\
\hline Konstanta & $\mathrm{a}$ & 0,468 & 0,703 & 0,484 & \\
\hline Information Quality $\left(\mathrm{X}_{1}\right)$ & $\beta_{1}$ & 0,450 & 2,523 & 0,014 & 0,299 \\
\hline Trust $\left(\mathrm{X}_{2}\right)$ & $\beta_{2}$ & 0,396 & 2,742 & 0,008 & 0,322 \\
\hline Dependent Variable & \multicolumn{5}{|c|}{ Intensi Pembelian $(\mathrm{Y})$} \\
\hline$F_{\text {hitung }}$ & \multicolumn{5}{|c|}{10,926} \\
\hline $\mathrm{R}_{\text {square }}\left(\mathrm{R}^{2}\right)$ & \multicolumn{5}{|c|}{0,252} \\
\hline $\mathrm{R}$ & \multicolumn{5}{|c|}{0,502} \\
\hline
\end{tabular}

Berdasarkan hasil analisis regresi linier berganda pada Tabel 3. diperoleh persamaan regresi linier berganda sebagai berikut:

$$
\mathrm{Y}=0,468+0,450 \mathrm{X}_{1}+0,396 \mathrm{X}_{2}
$$

Keterangan:

$\mathrm{Y}=$ Variabel terikat atau variabel intensi pembelian

$\mathrm{X}_{1}=$ Variabel bebas atau variabel information quality

$\mathrm{X}_{2}=$ Variabel bebas atau variabel trust

Berdasarkan persamaan tersebut dapat dijelaskan sebagai berikut:

Nilai $\beta_{1}$ sebesar 0,450 dan mempunyai nilai positif yang mempunyai arti bila information quality $\left(\mathrm{X}_{1}\right)$ meningkat dan variabel trust dianggap konstan, maka intensi pembelian konsumen akan naik sebesar 0,450. Begitu pula sebaliknya, apabila information quality $\left(\mathrm{X}_{1}\right)$ menurun dan variabel trust dianggap konstan, maka intensi pembelian konsumen akan turun sebesar 0,450 .

Nilai $\beta_{2}$ sebesar 0,396 dan mempunyai nilai positif yang mempunyai arti bila trust $\left(\mathrm{X}_{2}\right)$ meningkat dan variabel information quality dianggap konstan, maka intensi pembelian konsumen akan naik sebesar 0,396. Begitu pula sebaliknya, apabila trust $\left(\mathrm{X}_{2}\right)$ menurun dan variabel information quality dianggap konstan, maka intensi pembelian konsumen akan turun sebesar 0,396.

\section{$4.4 \quad$ Uji hipotesis dengan menggunakan Uji F (Uji Simultan)}

Uji $\mathrm{F}$ dilakukan untuk mengetahui apakah semua variabel bebas yang terdapat dalam model mempunyai pengaruh secara bersama-sama terhadap variabel terikat (Kuncoro,2009:239). 
Tabel 4.

Hasil Uji F

\begin{tabular}{|c|c|c|c|c|c|c|}
\hline \multicolumn{7}{|c|}{ ANOVA $^{\mathrm{a}}$} \\
\hline \multicolumn{2}{|c|}{ Model } & Sum of Squares & $\mathrm{df}$ & Mean Square & $\mathrm{F}$ & Sig. \\
\hline \multirow{3}{*}{1} & Regression & 10.707 & 2 & 5.353 & 10.926 & $.000^{\mathrm{b}}$ \\
\hline & Residual & 31.849 & 65 & .490 & & \\
\hline & $\mid$ & 42.556 & 67 & & & \\
\hline \multicolumn{7}{|c|}{ a. Dependent Variable: IntensiPembelian } \\
\hline \multicolumn{7}{|c|}{ b. Predictors: (Constant), Trust, InformationQuality } \\
\hline
\end{tabular}

Tabel 4. menunjukkan bahwa nilai $\mathrm{F}_{\text {hitung }} 10,926$ dan tingkat signifikansi nilai $\mathrm{F}_{\text {hitung }}<0,05$ yaitu 0,000 sehingga dapat disimpulkan bahwa information quality dan trust berpengaruh secara bersama-sama terhadap intensi pembelian secara online.

\subsection{Uji hipotesis dengan menggunakan Uji t (Uji Parsial)}

Uji t digunakan untuk menguji apakah terdapat pengaruh antara masingmasing variabel information quality $\left(\mathrm{X}_{1}\right)$ dan trust $\left(\mathrm{X}_{2}\right)$ terhadap intensi pembelian $(\mathrm{Y})$.

Tabel 5.

Hasil Uji t

\begin{tabular}{|c|c|c|c|c|c|c|}
\hline \multicolumn{7}{|c|}{ Coefficients $^{a}$} \\
\hline \multirow{2}{*}{\multicolumn{2}{|c|}{ Model }} & \multicolumn{2}{|c|}{$\begin{array}{l}\text { Unstandardized } \\
\text { Coefficients }\end{array}$} & $\begin{array}{l}\text { Standardized } \\
\text { Coefficients }\end{array}$ & \multirow[t]{2}{*}{$\mathrm{t}$} & \multirow[t]{2}{*}{ Sig. } \\
\hline & & B & Std. Error & Beta & & \\
\hline \multirow{3}{*}{1} & (Constant) & .468 & .666 & & .703 & .484 \\
\hline & InformationQuality & .450 & .178 & .291 & 2.523 & .014 \\
\hline & Trust & .396 & .145 & .316 & 2.742 & .008 \\
\hline
\end{tabular}

a. Dependent Variable: IntensiPembelian

Tabel 5. menunjukkan bahwa signifikansi pada uji t variabel information quality sebesar 0,014. Karena signifikansi pada uji $\mathrm{t}<0,05$ maka kesimpulannya adalah information quality berpengaruh secara parsial terhadap intensi pembelian secara online. Untuk variabel trust memiliki signifikansi pada uji t sebesar 0,008. Karena signifikansi pada uji $\mathrm{t}<0,05$ maka dapat disimpulkan bahwa trust berpengaruh secara parsial terhadap intensi pembelian secara online.

\subsection{Koefisien Korelasi (R) dan Determinasi Berganda $\left(\mathbf{R}^{2}\right)$ \\ Analisis koefisien korelasi dan} koefisien determinasi berganda merupakan alat analisis ketepatan dalam analisis regresi linier berganda. Pengujian koefisien korelasi berganda $(\mathrm{R})$ berguna untuk menunjukkan tingkat keeratan hubungan variabel bebas dan variabel terikat. Koefisien determinasi berganda $\left(\mathrm{R}^{2}\right)$ berguna untuk mengukur seberapa jauh kemampuan model dalam menerangkan variasi variabel terikat (Kuncoro, 2009:240). Tabel 6 merupakan hasil perhitungan koefisien korelasi (R) dan determinasi berganda $\left(\mathrm{R}^{2}\right)$. 
Tabel 6.

Hasil Koefisien Korelasi (R) dan Determinasi Berganda $\left(\mathrm{R}^{2}\right)$

\begin{tabular}{|l||c||}
\hline \multicolumn{1}{|c|}{ Variabel Bebas } & r parsial \\
\hline \hline Konstanta & 0,299 \\
\hline \hline Information Quality $\left(\mathrm{X}_{1}\right)$ & 0,322 \\
\hline \hline Trust $\left(\mathrm{X}_{2}\right)$ & Intensi Pembelian $(\mathrm{Y})$ \\
\hline \hline Dependent Variable & 0,252 \\
\hline \hline $\mathrm{R}_{\text {square }}\left(\mathrm{R}^{2}\right)$ & 0,502 \\
\hline \hline $\mathrm{R}$ & \\
\hline
\end{tabular}

Berdasarkan Tabel 6. dapat diketahui bahwa nilai $R$ yaitu 0,502 berarti variabel bebas memiliki keterikatan yang erat dengan variabel terikat karena nilainya di atas 0,5 . Hasil nilai koefisien determinasi berganda $\left(\mathrm{R}^{2}\right)$ sebesar 0,252 berarti angka ini menunjukkan bahwa sekitar $25,2 \%$ intensi pembelian konsumen dapat dijelaskan oleh information quality dan trust, sedangkan $74,8 \%$ dijelaskan oleh variabel-variabel lain diluar model penelitian seperti pengaruh variabel kualitas produk, kualitas pelayanan, kualitas sistem, harga, faktor personal konsumen, promosi, distribusi, tempat, dan sebagainya.

\subsection{Koefisien Korelasi Parsial (r)}

Analisis koefisien korelasi parsial (r) digunakan untuk mengetahui keeratan pengaruh masing-masing variabel bebas terhadap variabel terikat, yang mana variabel bebas yang lain dianggap tetap (Haryanto, 2011:38).

Berdasarkan Tabel 6. dapat diketahui bahwa nilai koefisien korelasi parsial variabel information quality $\left(\mathrm{X}_{1}\right)$ yaitu 0,299.
Sedangkan nilai koefisien korelasi parsial variabel trust $\left(\mathrm{X}_{2}\right)$ lebih besar yaitu 0,322 . Hal ini menunjukkan bahwa trust secara parsial mempunyai pengaruh paling dominan terhadap intensi pembelian secara online.

\subsection{Uji Asumsi Klasik}

Uji asumsi klasik bertujuan untuk mendapatkan persamaan yang paling tepat untuk mengukur regresi sehingga meminimalkan jumlah kuadrat kesalahan dengan menggunakan metode kuadrat terkecil atau method of ordinary least square (OLS). Uji asumsi klasik ada empat (Ghozali, 2011:160), yaitu:

\subsubsection{Uji Normalitas}

Model regresi yang bagus adalah model regresi yang residualnya berdistribusi normal. Uji normalitas digunakan untuk menguji apakah dalam model regresi, residualnya mempunyai distribusi normal atau tidak. Uji normalitas dapat dilakukan dengan menggunakan uji KolmogorovSmirnov (Widjajanti, 2008:12). 
Tabel 7.

Hasil Uji Normalitas Data

\begin{tabular}{|c|c|c|}
\hline \multicolumn{3}{|c|}{ One-Sample Kolmogorov-Smirnov Test } \\
\hline & & Unstandardized Residual \\
\hline \multicolumn{2}{|l|}{$\mathrm{N}$} & 68 \\
\hline \multirow{2}{*}{ Normal Parameters ${ }^{a, b}$} & Mean & $0 \mathrm{E}-7$ \\
\hline & Std. Deviation & .68945827 \\
\hline \multirow{3}{*}{ Most Extreme Differences } & Absolute & .075 \\
\hline & Positive & .044 \\
\hline & Negative & -.075 \\
\hline \multicolumn{2}{|l|}{ Kolmogorov-Smirnov Z } & .618 \\
\hline \multicolumn{2}{|l|}{ Asymp. Sig. (2-tailed) } & 840 \\
\hline \multicolumn{3}{|c|}{ a. Test distribution is Normal. } \\
\hline \multicolumn{2}{|l|}{ b. Calculated from data. } & \\
\hline
\end{tabular}

Berdasarkan Tabel 7. dapat diketahui bahwa nilai signifikansi uji KolmogorovSmirnov $>0,05$ yaitu 0,840 sehingga dapat disimpulkan bahwa residual model regresi berdistribusi normal.

\subsubsection{Uji Multikolinieritas}

Model regresi yang baik seharusnya tidak terjadi korelasi di antara variabel bebas.
Uji multikolinieritas bertujuan untuk menguji ada tidaknya korelasi antar variabel bebas. Uji ini dilihat berdasarkan nilai Variance Inflation Factor (VIF) yang diperoleh. Jika variabel-variabel bebas saling berkorelasi (diatas 0,9 ) dan nilai tolerance < 0,10 atau sama dengan nilai VIF $>10$ maka mengindikasikan adanya multikolinieritas (Widjajanti, 2008:12).

Tabel 8.

Hasil Uji Multikolinieritas

\begin{tabular}{|l||c|c|}
\hline \multirow{2}{*}{\multicolumn{1}{|c||}{ Variabel }} & \multicolumn{2}{c|}{ Colinierity Statistics } \\
\cline { 2 - 3 } & Tolerance & VIF \\
\hline \hline Information Quality & 0,867 & 1,154 \\
\hline \hline Trust & 0,867 & 1,154 \\
\hline
\end{tabular}

Berdasarkan hasil uji multikolinieritas pada Tabel 8. dapat diketahui bahwa nilai tolerance $>0,10$ yaitu sebesar 0,867 dan nilai VIF untuk variabel bebas penelitian $<10$ yaitu sebesar 1,154 , sehingga bisa dinyatakan bahwa tidak ada multikolinieritas di antara variabel bebas.

\subsubsection{Uji Heteroskedastisitas}

Model regresi yang baik adalah homokedastisitas atau tidak terjadi heteroskedastisitas. Heteroskedastisitas berarti terdapat varian variabel yang tidak sama dalam model regresi yang terbentuk. Deteksi adanya heteroskedastisitas dapat dilakukan dengan menggunakan model Glejser dengan melihat signifikansi output yang lebih besar (Widjajanti, 2008:10). 
Tabel 9.

Hasil Uji Heteroskedastisitas

\begin{tabular}{|c||l|c|c|}
\hline \hline No. & \multicolumn{1}{|c|}{ Koefisien } & T & Sig. \\
\hline \hline 1. & Konstanta & 1,499 & 0,139 \\
\hline \hline 2. & Information Quality & $(0,677)$ & 0,501 \\
\hline \hline 3. & Trust & 0,770 & 0,444 \\
\hline \hline \multicolumn{2}{|l}{} \\
\hline
\end{tabular}

Nilai tingkat signifikansi $\mathrm{t}_{\text {statistik }}$ pada Tabel 9. di atas menunjukkan nilai lebih besar dari 0,05 sehingga dapat dijelaskan bahwa tidak ada heteroskedastisitas.

\subsubsection{Uji Autokorelasi}

Dalam analisis regresi linier berganda, tidak boleh terdapat korelasi kesalahan (error) penelitian sebelumnya. Untuk mendeteksi ada atau tidaknya hubungan korelasi tersebut, dilakukan uji autokorelasi. Uji autokorelasi adalah korelasi antara variabel gangguan satu observasi dengan variabel gangguan oberservasi lain (Ghozali, 2011:110). Ada tidaknya autokorelasi dalam penelitian dapat dideteksi dengan menggunakan uji Durbin-Watson, dengan kriteria sebagai berikut:

a. Jika nilai $\mathrm{d}, 1.5<\mathrm{d}<2.5$, maka data tidak mengalami autokorelasi.

b. Jika nilai $\mathrm{d}, 0 \leq \mathrm{d} \leq 1.5$, maka data memiliki autokorelasi positif.

c. Jika nilai $\mathrm{d}, 2.5<\mathrm{d} \leq 4$, maka data memiliki autokorelasi negatif.

Tabel 10.

Hasil Uji Autokorelasi

\begin{tabular}{|c|c|c|c|c|c|}
\hline \multicolumn{6}{|c|}{ Model Summary ${ }^{b}$} \\
\hline Model & R & R Square & $\begin{array}{l}\text { Adjusted R } \\
\text { Square }\end{array}$ & $\begin{array}{l}\text { Std. Error of the } \\
\text { Estimate }\end{array}$ & Durbin-Watson \\
\hline 1 & $.502^{\mathrm{a}}$ & .252 & .229 & .69998 & 2.326 \\
\hline \multicolumn{6}{|c|}{ a. Predictors: (Constant), Trust, InformationQuality } \\
\hline \multicolumn{6}{|c|}{ b. Dependent Variable: IntensiPembelian } \\
\hline
\end{tabular}

Hasil Uji pada Tabel 10. berdasarkan nilai Durbin-Watson dan diperoleh nilai sebesar 2,326. Dengan ketentuan jika nilai Durbin-Watson $1.5<\mathrm{d}<2.5$, maka dapat disimpulkan bahwa data tidak mengalami autokorelasi.

\subsection{Analisis Hipotesis}

\subsubsection{Pengaruh Information Quality terhadap Intensi Pembelian Secara Online}

Hasil penelitian ini menunjukkan bahwa tinggi rendahnya intensi pembelian konsumen secara online ternyata dipengaruhi oleh penilaian responden terhadap information quality. Hal ini berdasarkan pada hasil pengujian pengaruh yang menunjukkan bahwa information quality berpengaruh terhadap intensi pembelian konsumen secara online di Lady Reptile.

Temuan penelitian ini mendukung penelitian Ho, et al., (2010:630) yang menemukan bahwa berbagai informasi yang diterima konsumen berpengaruh terhadap perilaku konsumen dalam melakukan berbagai aktivitas online termasuk juga pembelian online yang dilakukan oleh konsumen. Berbagai informasi yang diterima 
oleh konsumen mendorong konsumen untuk berperilaku tertentu berdasarkan informasi yang didapatkan dalam kegiatan pembelian online. Oleh karena itu, kualitas informasi dengan sendirinya mempengaruhi perilaku pembelian konsumen sehingga informasi yang berkualitas akan memperkuat intensi pembelian konsumen secara online. Penelitian yang dilakukan oleh Sam dan Tahir (2010:20) juga menemukan bahwa terdapat berbagai faktor yang mempengaruhi perilaku pembelian konsumen secara online dan diantaranya adalah information quality.

Di sisi lain, hasil penelitian ini berbeda dengan hasil penelitian Chuang dan Jen Fan (2011) yang menemukan bahwa information quality tidak mempengaruhi intensi pembelian konsumen secara online. Hal ini dikarenakan adanya perbedaan pada objek penelitian, yang mana objek penelitian Chuang dan Jen Fan (2011) adalah online bookstore yaitu the first electronic bookstore di Taiwan yang didirikan pada tahun 1995, sehingga pada tahun 2012 ini sudah berusia 17 tahun. Usaha yang telah berdiri selama 17 tahun dinilai memiliki kredibilitas yang tinggi bagi responden sehingga responden mengabaikan information quality dalam website untuk mendukung intensi pembelian. Sedangkan objek pada penelitian ini adalah Lady Reptile yang didirikan pada bulan Mei 2010 sehingga saat ini baru berumur dua setengah $(2,5)$ tahun.

Selain itu, perbedaan hasil penelitian tersebut juga dikarenakan adanya perbedaan pengalaman responden dalam melakukan transaksi dengan objek penelitian yang diteliti, yang mana responden Chuang dan Jen Fan (2011) mayoritas telah melakukan pembelian sebanyak satu kali dalam satu bulan atau lebih yaitu sebesar $70,1 \%$, jumlah terbesar kedua yaitu telah melakukan pembelian dua sampai lima kali dalam sebulan sebesar $27,4 \%$, dan pembelian enam kali atau lebih selama satu bulan sebesar
2,4\%. Oleh karena itu, dapat dijelaskan bahwa tingkat pengalaman responden Chuang dan Jen Fan (2011) dalam melakukan transaksi jauh lebih tinggi dibandingkan dengan responden penelitian ini, yang mana mayoritas responden Lady Reptile telah melakukan pembelian sebanyak dua kali sejak Lady Reptile berdiri. Perbedaan tingkat pengalaman ini juga menyebabkan responden penelitian ini lebih peka terhadap kualitas informasi yang disajikan. Berdasarkan perbedaan tersebut, hasil penelitian ini mampu menjelaskan bahwa hasil penelitian Chuang dan Jen Fan (2011) untuk pengaruh information quality terhadap intensi pembelian tidak dapat berlaku universal, tetapi mempunyai keterkaitan dengan karakteristik konsumen yang diteliti pada objek penelitian.

Pada hasil uji t, variabel information quality memiliki nilai signifikansi 0,014. Karena nilai signifikansi pada uji $\mathrm{t}<0,05$ maka dapat dinyatakan bahwa information quality berpengaruh secara parsial terhadap intensi pembelian secara online pada Lady Reptile.

Menurut Lady Reptile sendiri, information quality adalah sejauh mana informasi dapat secara akurat dan memenuhi kebutuhan konsumen Lady Reptile dalam pengambilan keputusan pembelian dan meningkatkan intensi pembelian diwaktu yang akan datang. Contohnya, gambar dan informasi mengenai produk yang disajikan sesuai dengan kondisi yang sebenarnya. Misalnya konsumen memesan Leopard Gecko normal umur delapan bulan dengan motif yang sesuai dengan gambar yang dipilih, maka yang datang juga Leopard Gecko normal umur delapan bulan dengan motif yang sesuai dengan gambar yang dipilih konsumen dan sesuai dengan informasi yang disajikan oleh Lady Reptile. Informasi yang diberikan juga relevan, yaitu memiliki manfaat bagi penerima informasi 
(konsumen). Misalnya rekomendasi produk, jenis reptil yang cocok untuk dipelihara konsumen, serta cara perawatan dan pemeliharaan reptil tersebut. Jadi, information quality yang diberikan untuk konsumen mempunyai banyak manfaat untuk membantu dalam pengambilan keputusan pembelian yang nantinya akan meningkatkan intensi pembelian dengan adanya pembelian ulang.

\subsubsection{Pengaruh Trust terhadap Intensi Pembelian Secara Online}

Hasil penelitian selanjutnya menunjukkan bahwa bahwa tinggi rendahnya intensi pembelian konsumen secara online ternyata juga dipengaruhi oleh tingkat kepercayaan (trust) konsumen atas layanan yang diberikan oleh Lady Reptile. Hal ini berdasarkan pada hasil pengujian pengaruh yang menunjukkan bahwa trust berpengaruh terhadap intensi pembelian konsumen secara online di Lady Reptile.

Temuan penelitian ini mendukung penelitian Zhu, et al., (2011:4) yang menemukan bahwa ketika tingkat kepercayaan rendah berarti semakin tinggi tingkat ketidakpastian yang dirasakan konsumen dan melahirkan kecemasan dalam belanja online. Artinya, ketika konsumen memiliki kepercayaan yang rendah maka menyebabkan rendahnya intensi pembelian konsumen secara online. Hasil penelitian ini juga mendukung penelitian Adityo (2011:24) yang menemukan bahwa trust konsumen terhadap layanan online mempengaruhi intensi pembelian konsumen secara online karena konsumen merasa yakin bahwa peritel online benar-benar dapat dipercaya.

Pada hasil uji t, variabel trust memiliki nilai signifikansi 0,008 . Karena nilai signifikansi pada uji $\mathrm{t}<0,05$ maka dapat dinyatakan bahwa trust berpengaruh secara parsial terhadap intensi pembelian secara online pada Lady Reptile.
Menurut Lady Reptile sendiri, trust merupakan salah satu faktor utama penentu keputusan pembelian konsumen secara online, karena keputusan pembelian tidak akan pernah terjadi jika tidak ada kepercayaan. Begitu pula dengan intensi pembelian. Adanya risiko belanja online seperti penipuan, jenis dan kualitas yang tidak sesuai dengan keinginan konsumen, serta konsumen tidak dapat melihat secara langsung menyebabkan adanya ketidakpercayaan konsumen terhadap penjual. Oleh karena itu, jika kepercayaan dapat dibangun, maka intensi pembelian secara online akan dapat meningkat serta memungkinkan adanya perekomendasian dari konsumen kepada kerabatnya yang lain.

\subsubsection{Pengaruh Information Quality dan Trust terhadap Intensi Pembelian Secara Online}

Hasil penelitian secara keseluruhan menunjukkan bahwa bahwa tinggi rendahnya intensi pembelian konsumen secara online ternyata dipengaruhi oleh information quality dan tingkat trust konsumen atas layanan yang diberikan oleh Lady Reptile. Hal ini didasarkan pada hasil uji $\mathrm{F}$ dengan nilai signifikansi 0,000 . Karena nilai signifikansi pada uji $\mathrm{F}<0,05$ maka dapat dinyatakan bahwa information quality dan trust secara bersama-sama berpengaruh terhadap intensi pembelian secara online pada Lady Reptile.

Hasil penelitian ini mendukung hasil penelitian yang dilakukan oleh Adityo (2011:24) yang menemukan bahwa trust memiliki keterkaitan dengan intensi pembelian, tetapi trust juga didasari oleh adanya information quality, karena ketika informasi yang diberikan oleh peritel online tidak dapat dipercaya berarti tingkat kepercayaan konsumen juga rendah. Semakin rendahnya tingkat kepercayaan konsumen menyebabkan intensi pembelian 
konsumen secara online juga semakin rendah. Oleh karena itu, dapat dijelaskan bahwa terdapat keterkaitan antara information quality, trust, dan intensi pembelian konsumen secara online pada Lady Reptile.

\section{KESIMPULAN DAN SARAN}

Semua faktor yang diukur dalam penelitian ini mempengaruhi intensitas pembelian online pada Lady Reptile. Faktor trust memiliki persentase tertinggi sebesar $32,2 \%$ dibandingkan information quality sebesar 29,9\%. Oleh karena itu disarankan untuk melakukan promosi pada komunitaskomunitas pencinta reptile maupun hewan lainnya baik secara online maupun offline. Disamping itu penelitian ini perlu dilanjutkan dengan menambahkan variabel lain seperti kemudahan, website design, system quality, dan service quality. 


\section{DAFTAR PUSTAKA}

Adityo, Benito. 2011. Analisis Pengaruh Kepercayaan, Kemudahan, dan Kualitas Informasi Terhadap Keputusan Pembelian Secara Online di Situs kaskus. Skripsi. Semarang: Progam Sarjana Fakultas Ekonomi Universitas Diponegoro.

Alkhattabi, et al. 2010. "Information Quality Framework for E-Learning Systems". Knowledge Management \& E-Learning: An International Journal, Vol.02, No.04, 2010:340-345.

Avitia, et al. 2011. Structural Equation Modelling of Consumer Acceptance of Organic Food in Spain. 2011:1-36.

Chuang, Huan-Ming dan Chwei-Jen Fan. 2011. "The Mediating Role of Trust in The Relationship Between E-Retailer Quality and Customer Intention of Online Shopping”. African Journal of Business Management, Vol.02, No.22, September 2011:9522-9529.

Ganguly, et al. 2010. "The Effects of Website Design on Purchase Intention in Online Shopping: The Mediating Role of Trust and The Moderating Role of Culture". International Journal of Electronic Business, Vol.08, No.4/5, 2010:302-330.

Ghozali, Imam. 2011. Aplikasi Analisis Multivariate Dengan Program SPSS. Semarang: BP Universitas Diponegoro.

Handayani, Sisti. 2010. Laris Manis Jual-Beli Lewat Kaskus. Yogyakarta: MediaKom.

Ho, et al. 2010. "The Mediate Effect of Trust on Organization Online Knowledge Sharing: An Empirical Study". International Journal of Information Technology \& Decision Making, Vol.09, No.04, 2010:625-644.

Hong, Ilyoo B. dan Hwihyung Cho. 2011. 'The Impact of Consumer Trust on Attitudinal Loyalty and Purchase Intentions in B2C E-Marketplaces: Intermediary Trust vs. Seller Trust". International Journal of Information Management: The Journal for Information Professionals, Vol.31, No.05, Oktober 2011:469-479.

Kuncoro, Mudrajad. 2009. Metode Riset untuk Bisnis \& Ekonomi Edisi 3. Jakarta: Erlangga.

Popovic, Ales dan Andreja Habjan. 2012. "Exploring the Impact of Decision Making Culture on the Information Quality - Information Use Relationship: An Empirical Investigation of Two Industries". Issues in Informing Science and Information Technology, Vol.09, 2012:125-134.

Priyatno, Duwi. 2009. 5 Jam Belajar Olah Data dengan SPSS 17. Jakarta: Andi Offset.

Rieh, Soo Young dan Brian Hilligoss. 2008. College Students' Credibility Judgements in the InformationSeeking Process. Massachusetts Institute of Technology, The MIT Press, 2008:49-72.

Sam, Mohd Fazli Mohd dan Md Nor Hayati Tahir. 2010. "Website Quality And Consumer Online Purchase Intention Of Air Ticket”. International Journal of Basic \& Applied Sciences IJBAS, Vol.09, No.10, 2010:20-25.

Setiawan, Nugraha. 2008. Penentuan Ukuran Sampel memakai Rumus Slovin dan Tabel Krejcie-Morgan: Telaah Konsep dan Aplikasinya. Bandung: Universitas Padjdjaran.

Sugiyono. 2008. Metode Penelitian Pendidikan. Bandung: Alfabeta.

Susrini, Ni Ketut. 2010. Cara Gampang Bikin Toko Online. Jakarta: PT. Grasindo.

Utomo, Eko Priyo. 2009. Meraup Kekayaan Lewat Internet dengan Toko Online. Yogyakarta: MediaKom.

Widarjono, Agus. 2010. Analisa Statistika Multivariat Terapan. Yogyakarta: UPP STIM YKPN.

Widjajanti, AP. 2008. "Analisis Faktor-Faktor Yang Mempengaruhi Kinerja manajerial Bank Perkreditan Rakyat (BPR) di Kota Surakarta”. Excellent, Vol.01, No.02, September 2008:1-16.

Zhu, et al. 2011. "Mr. Risk! Please Trust Me: Trust Antecedents that Increase Online Consumer Purchase Intention". Journal of Internet Banking and Commerce, Vol.16, No.03, Desember 2011:1-23. 